Eur. J. Clin. Chem. Clin. Biochem.

Vol. 30, 1992, pp. 229-233

(C) 1992 Walter de Gruyter \& Co.

Berlin $\cdot$ New York

\title{
A Highly Sensitive and Rapid Radioimmunoassay for the Determination of Arginine ${ }^{8}$-Vasopressin
}

\author{
By A. L. Gerbes ${ }^{1}$, R. Witthaut ${ }^{1}$, W. K. Samson ${ }^{2}, W$. Schnizer $^{3}$ and Angelika M. Vollmar ${ }^{4}$ \\ ${ }^{1}$ Medizinische Klinik II, Klinikum Großhadern, Universität München \\ ${ }^{2}$ Department of Anatomy, University of Missouri, Columbia, Missouri \\ ${ }^{3}$ Privatklinik Raphael, Bad Griesbach \\ ${ }^{4}$ Institut für Pharmakologie, Toxikologie und Pharmazie, Tierärztliche Fakultät, Universität München
}

(Received October 11, 1991/January 7, 1992)

Summary: A highly sensitive radioimmunoassay for arginine ${ }^{8}$-vasopressin (argipressin; INN) measurement was developed using Amberlite XAD 2 resin columns to extract arginine ${ }^{8}$-vasopressin from acidified human plasma. Arginine ${ }^{8}$-vasopressin was determined by a rapid radioimmunoassay method $\left(2 \times 20^{\circ} \mathrm{h}\right)$ using a specific antibody and ${ }^{125}$ I-labelled antigen. The bound fraction was separated by adsorption of the free fraction onto bovine serum albumin-coated charcoal; this resulted in low unspecific binding of less than $2 \%$. Recovery experiments in the physiological range resulted in a mean ( \pm SEM) recovery of $88 \pm 3 \%$. The radioimmunoassay consistently yielded a detection limit of $0.3 \mathrm{ng} / 1\left(\mathrm{ED}_{90}\right)$ and a mean $50 \%$ binding intercept $\left(\mathrm{ED}_{50}\right)$ of $3.5 \mathrm{ng} / \mathrm{l}$. Arginine ${ }^{8}$-vasopressin immunoreactivity was characterized by reverse-phase high performance liquid chromatography, which confirmed the specificity of the assay. Serial plasma dilution curves paralleled the standard curve. The intra- and inter-assay variations were $9.4 \%$ and $15 \%$, respectively. Arginine ${ }^{8}$-vasopressin concentrations in healthy subjects were determined in normal hydration status $(2.2 \pm 0.3 \mathrm{ng} / \mathrm{l} ; \mathrm{n}=11)$, as well as during suppression by water immersion $(1.5 \pm 0.2 \mathrm{ng} / \mathrm{l} ; \mathrm{n}=11)$ or by water loading $(1.6 \pm 0.2 \mathrm{ng} / \mathrm{l}$; $\mathrm{n}=8$ ). Thus, this assay allows for a sensitive, accurate and rapid quantification of plasma arginine ${ }^{8}$ vasopressin concentrations.

\section{Introduction}

Alterations of arginine ${ }^{8}$-vasopressin plasma concentrations seem to be involved in the abnormal water handling that is present in several diseases. Thus, investigations in patients with congestive heart failure $(1-3)$, hyperaldosteronism (4) or syndrome of inappropriate antidiuresis $(5,6)$ demonstrated abnormal arginine $^{8}$-vasopressin secretion as a determinant of impaired water balance. Furthermore, any investigation of the physiological regulation of water homeostasis should comprise determination of arginine ${ }^{8}$ vasopressin plasma concentrations $(7,8)$. Therefore, an accurate determination of arginine ${ }^{8}$-vasopressin is important for both physiological and clinical purposes. Efforts to obtain an exact measurement of the rather low plasma concentrations of arginine ${ }^{8}$-vaso- pressin by radioimmunoassay have been hampered by the presence of different interfering factors which are still only partially characterized. Thus, limited specificity is inherent in the methods using direct radioimmunoassay for arginine ${ }^{8}$-vasopressin in plasma $(9,10)$, necessitating plasma extraction before radioimmunoassay of the neurohypophyseal peptide. Different extraction procedures have been used, including the use of acetone and petroleum ether $(11,12)$, cold ethanol (13) or Bentonite (14), but they show poor and variable recoveries $(11,13)$. Furthermore, several radioimmunoassays for arginine ${ }^{8}$-vasopressin involve complicated separation techniques, and in order to obtain adequate sensitivity they employ incubation periods of up to 7 days $(9,15)$. 
Therefore we have developed a simple, accurate and rapid method for determining arginine ${ }^{8}$-vasopressin following extraction from plasma. The method has a very low detection limit.

\section{Materials and Methods}

\section{Material}

\section{Sample preparation and extraction}

Blood was collected in disodium ethylenediaminetetraacetate coated tubes and immediately centrifuged at $2000 \mathrm{~g}$ for $10 \mathrm{~min}$ at $4{ }^{\circ} \mathrm{C}$. The plasma was removed, treated with phenylmethylsulphonylfluoride $(5 \mathrm{mmol} / \mathrm{l})$ and acidified with acetic acid to $\mathrm{pH} 5.5(2.5 \mathrm{~mol} / \mathrm{l})$. For extraction the plasma samples were adsorbed as $1 \mathrm{ml}$ aliquots to activated Amberlite XAD 2 resin (Serva, Heidelberg, Germany) chromatography columns (BioRad Laboratories, Richmond, CA 94804) followed by washing with trifluoroacetic acid $(1 \mathrm{mmol} / \mathrm{l})$. The elution was performed using a mobile phase consisting of $1 \mathrm{~mol} / \mathrm{l}$ acetonitrile $(80 \%)$ and $1 \mathrm{mmol} / 1$ trifluoroacetic acid $(20 \%)$. The lyophilized samples were reconstituted in $300 \mu$ lassay buffer I.

\section{Recovery}

Recovery experiments were performed by parallel extraction of $1,2,4$ and $8 \mathrm{pg}$ synthetic arginine ${ }^{8}$-vasopressin (Bissendorf Biochemicals $\mathrm{GmbH}$, Hannover, Germany) added to $1 \mathrm{ml}$ aliquots of different plasma samples.

\section{Assay buffers}

Two assay buffers were used in this radioimmunoassay.

Assay buffer I was prepared with $20 \mathrm{~g} / 1$ of bovine serum albumin in $50 \mathrm{mmol} / \mathrm{l}$ phosphate buffer (pH 7.4) containing $5 \mathrm{mmol} / 1$ phenylmethylsulphonylfluoride, $0.1 \mathrm{~mol} / 1$ sodium chloride, $10 \mathrm{mmol} / 1$ disodium ethylenediaminetetraacetate and $0.1 \mathrm{~mol} / 1$ Triton X-100. After incubation for $4 \mathrm{~h}$ at $56^{\circ} \mathrm{C}$ the buffer was diluted 10 fold. Neomycin sulphate $(2 \mathrm{~g} / \mathrm{l})$ and sodium azide $(1 \mathrm{~g} / \mathrm{l})$ were then added and the $\mathrm{pH}$ adjusted to 7.4.

For assay buffer II dissolved gelatine $(1 \mathrm{~g} / \mathrm{l})$ was added to 20 $\mathrm{mmol} / \mathrm{l}$ phosphate buffer containing $0.15 \mathrm{~mol} / \mathrm{l}$ sodium chloride, $0.1 \mathrm{~g} / 1$ bovine serum albumin and $0.1 \mathrm{~g} / 1$ thimerosal. Thereafter the $\mathrm{pH}$ was adjusted with sodium hydroxide $(10 \mathrm{~mol} / \mathrm{l})$ to 7.4 .

\section{Standard curve}

Known amounts of synthetic arginine ${ }^{8}$-vasopressin were serially diluted ranging from 80 to $0.08 \mathrm{ng} / \mathrm{l}$ in assay buffer I.

\section{Methods \\ Assay protocol}

Polyclonal antibody (Nol 728-6), generated against synthetic arginine ${ }^{8}$-vasopressin bovine thyroglobulin conjugates in rabbits (16), was diluted to bind about a third of the total radiolabelled antigen added in the absence of unlabelled antigen. Antiserum $(100 \mu$, end dilution $1: 50000)$ was added to standards and extracted antigens. Incubation was carried out in polypropylene tubes for $20 \mathrm{~h}$ at $4{ }^{\circ} \mathrm{C}$. Then, $1.6 \mathrm{pg} /$ tube ${ }^{125} \mathrm{I}-$ labelled arginine ${ }^{8}$-vasopressin (Amersham Braunschweig, Germany, $74 \mathrm{TBq} / \mathrm{mmol}(2000 \mathrm{Ci} / \mathrm{mmol}) ; 100 \mu \mathrm{l})$ was added, followed by incubation at $4{ }^{\circ} \mathrm{C}$ for a further $20 \mathrm{~h}$.

In order to determine cross-reactivities of the antibody with other peptides, standard curves of the radioimmunoassay were performed with ocytocin, atrial natriuretic peptide, angiotensin II and lysine ${ }^{8}$-vasopressin, respectively, instead of unlabelled arginine ${ }^{8}$-vasopressin.

\section{Separation}

Separation was performed by adding $500 \mu \mathrm{l}$ of bovine serum albumin-coated charcoal ( $29 \% / 71 \%$, by weight) dissolved in assay buffer II. After $10 \mathrm{~min}$, standards and samples were centrifuged at $4{ }^{\circ} \mathrm{C}$ for $10 \mathrm{~min}$ at $2000 \mathrm{~g}$ and the supernatant was counted (LKB, Turku, Finland, $80 \%$ efficiency) in triplicate.

Non-specific binding was determined by performing the radioimmunoassay without antibody $(n=9)$.

\section{Reverse-phase-HPLC}

Arginine ${ }^{8}$-vasopressin immunoreactivity was characterized by reverse-phase high performance liquid chromatography $(n=6)$. For calibration a standard of $200 \mathrm{pg}$ synthetic arginine $^{8}$-vasopressin was dissolved in $250 \mu \mathrm{l}$ acetonitrile and submitted to reverse-phase high performance liquid chromatography $\left(\mathrm{C}_{8}\right.$-ultrapore TM column [5 $\left.\mu \mathrm{m}\right]$, Beckman San Ramon, U.S.A.). Standard and extracted samples were eluted with a linear gradient from $15 \%-45 \%$ acetonitrile in $1 \mathrm{mmol} / \mathrm{l}$ trifluoroacetic acid in $35 \mathrm{~min}$ (flow rate $0.5 \mathrm{ml} / \mathrm{min}$, fraction size $0.5 \mathrm{ml} /$ tube). Subsequently, the hormone contents of the fractions were measured by radioimmunoassay.

\section{Water immersion}

Water immersion was performed as described in detail elsewhere (17-19). Briefly, following $1 \mathrm{~h}$ in the sitting position at room temperature $\left(28^{\circ} \mathrm{C}\right)$ beside the water thank, 11 healthy, normally hydrated subjects were immersed to the level of the neck into thermoneutral water $\left(34.5^{\circ} \mathrm{C}\right)$ for $1 \mathrm{~h}$ followed by $1 \mathrm{~h}$ outside the tank. Blood samples were taken immediately before, after $1 \mathrm{~h}$ immersion and $1 \mathrm{~h}$ after exiting the tank.

\section{Water loading}

After an overnight fast $(16 \mathrm{~h})$ blood samples (basal value) were taken from 8 healthy volunteers. Thereafter the subjects were orally water loaded with $20 \mathrm{ml} / \mathrm{kg}$ body weight within $30 \mathrm{~min}$ and blood samples were taken $1 \mathrm{~h}$ later.

All data are given as mean \pm standard error of the mean. Significance of differences was tested by the Student t-test.

\section{Results}

Recovery experiments $(n=11)$ with physiological concentrations of synthetic arginine ${ }^{8}$-vasopressin added to different plasma samples prior to extraction showed a linear relationship between added and determined arginine ${ }^{8}$-vasopressin concentration with a mean recovery of $88 \pm 3 \%$. Figure 1 illustrates a typical standard curve for the radioimmunoassay of arginine ${ }^{8}$-vasopressin with the $50 \%$ binding intercept $\left(\mathrm{ED}_{50}\right)$ at $3.5 \mathrm{ng} / \mathrm{l}$ and a lower detection limit $\left(\mathrm{ED}_{90}\right)$ of $0.3 \mathrm{ng} / \mathrm{l}(\mathrm{n}=8)$. Serial dilutions of $0.5,1,2$ and $4 \mathrm{ml}$ plasma paralleled the standard curve. The intraassay coefficient of variation $(n=8)$ averaged $9.4 \%$, the inter-assay coefficient of variation $(n=8)$ was 


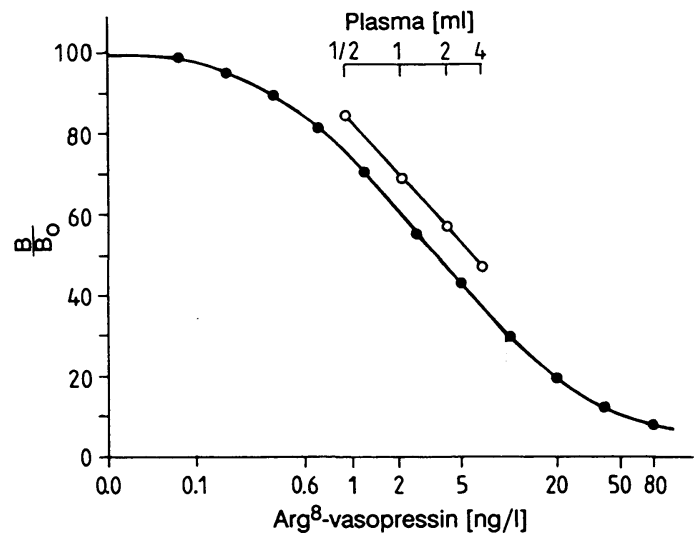

Fig. 1. Typical standard curve with a low detection limit $\left(\mathrm{ED}_{90}\right.$ $=0.3 \mathrm{ng} / 1, \mathrm{ED}_{50}=3.5 \mathrm{ng} / 1$ and $\left.\mathrm{ED}_{10}=58.1 \mathrm{ng} / \mathrm{l}\right)$. Serial dilutions of plasma paralleled the standard curve, confirming the accurate measurement of plasma samples.

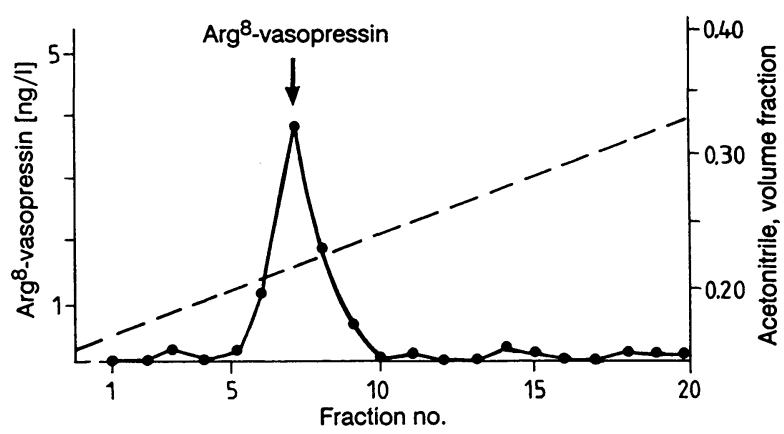

Fig. 2. Coelution of arginine ${ }^{8}$-vasopressin immunoreactivity of an extracted plasma sample with synthetic arginine ${ }^{8}$ vasopressin by reverse-phase high performance liquid chromatography analysis, confirming the specificity of the assay.

$15 \%$. No cross-reactivity of the anti-arginine ${ }^{8}$-vasopressin antibody to ocytocin, atrial natriuretic peptide and angiotensin II could be observed. The crossreactivity to lysine ${ }^{8}$-vasopressin was $3 \%$. The nonspecific binding was less than $2 \%$.
Reverse-phase high performance liquid chromatography analysis revealed coelution of immunoreactive arginine ${ }^{8}$-vasopressin with synthetic arginine ${ }^{8}$-vasopressin as a single peak (fig. 2).

Central volume stimulation by $1 \mathrm{~h}$ head-out water immersion in 11 healthy subjects produced a significant drop $(2.2 \pm 0.3$ vs. $1.5 \pm 0.2 \mathrm{ng} / \mathrm{l}, \mathrm{p}<0.05)$ of arginine $^{8}$-vasopressin plasma concentrations. In the recovery period, arginine ${ }^{8}$-vasopressin returned to baseline concentrations $(1.5 \pm 0.2$ vs. $2.0 \pm 0.3 \mathrm{ng} / \mathrm{l}$, $\mathrm{p}<0.05$ ). Oral water loading of 8 healthy subjects significantly decreased arginine ${ }^{8}$-vasopressin plasma concentrations $(2.0 \pm 0.2$ vs. $1.6 \pm 0.2 \mathrm{ng} / \mathrm{l}$, $\mathrm{p}<0.05)$ as well as plasma osmolality $(282 \pm 5.5$ vs. $274 \pm 4.4 \mathrm{mosmol} / \mathrm{kg}, \mathrm{p}<0.05$ ). Arginine ${ }^{8}$-vasopressin plasma concentrations were significantly correlated with plasma osmolality $(\mathrm{r}=0.83, \mathrm{p}<0.01)$.

\section{Discussion}

Due to the very low plasma concentration of arginine $^{8}$-vasopressin and the presence of inadequately characterized interfering factors, the development of a sensitive and specific radioimmunoassay for arginine ${ }^{8}$-vasopressin has proved to be more difficult than for many other peptides (9).

In contrast to a variety of less specific antisera raised for vasopressin determination $(20-23)$, we used a highly specific one (16). Due to the specificity of this antibody (confirmed by cross-reactivity experiments and high performance liquid chromatography analysis), the extraction procedure was simpler than those reported previously for other methods. The usefulness of this Amberlite XAD 2 resin extraction procedure was confirmed by the linear relationship between added and measured arginine ${ }^{8}$-vasopressin concentration in the recovery experiments, as well as by a reliable mean recovery rate of $88 \%$.

Tab. 1. Arginine ${ }^{8}$-vasopressin assays described by different authors

\begin{tabular}{|c|c|c|c|c|c|}
\hline Author & $\begin{array}{l}\text { Lower detection } \\
\text { limit }\end{array}$ & $\mathrm{ED}_{50}$ & $\begin{array}{l}\text { Mean } \\
\text { recovery }\end{array}$ & $\begin{array}{l}\text { Incubation } \\
\text { time }\end{array}$ & $\begin{array}{l}\text { HPLC } \\
\text { analysis }\end{array}$ \\
\hline Bichet, D. G. (24) & $0.5 \mathrm{ng} / 1$ & $1.2 \mathrm{pg} / \mathrm{tube}^{*}$ & $102 \%$ & $120 \mathrm{~h}$ & + \\
\hline Bie, $P .(25)$ & $0.5 \mathrm{pg} / \mathrm{tube}^{*}$ & $8.5 \mathrm{pg} / \mathrm{tube}^{*}$ & $72 \%$ & $?$ & - \\
\hline Bodola, F. (26) & $0.4 \mathrm{ng} / 1$ & $4.6 \mathrm{ng} / 1$ & $80 \%$ & $32 \mathrm{~h}$ & - \\
\hline Durr, J.A. (27) & $0.2 \mathrm{pg} /$ tube*$^{*}$ & $5.0 \mathrm{pg} /$ tube* & $103 \%$ & $96 \mathrm{~h}$ & - \\
\hline Fyhrquist, $F$. (10) & $1.2 \mathrm{ng} / 1$ & $8.3 \mathrm{ng} / 1$ & $96 \%$ & $168 \mathrm{~h}$ & - \\
\hline Gerbes, A. L. (this paper) & $0.3 \mathrm{ng} / 1$ & $3.5 \mathrm{ng} / 1$ & $88 \%$ & $40 \mathrm{~h}$ & + \\
\hline Husain, M. K. (11) & $0.1 \mathrm{ng} / 1$ & $0.8 \mathrm{ng} / 1$ & $68 \%$ & $120 \mathrm{~h}$ & - \\
\hline Keil, L. C. (28) & $1.6 \mathrm{ng} / 1$ & $4.2 \mathrm{pg} /$ tube* $^{*}$ & $64 \%$ & $134 \mathrm{~h}$ & - \\
\hline Robertson, G. L. (9) & $0.5 \mathrm{ng} / 1$ & $1.1 \mathrm{pg} /$ tube* $^{*}$ & $96 \%$ & $168 \mathrm{~h}$ & - \\
\hline Ross, M. G. (29) & $0.8 \mathrm{ng} / 1$ & $4.0 \mathrm{ng} / 1$ & $70 \%$ & $?$ & - \\
\hline Samson, W. K. (16) & $1.0 \mathrm{pg} / \mathrm{tube}^{*}$ & $25.0 \mathrm{pg} / \mathrm{tube}^{*}$ & $80 \%$ & $96 \mathrm{~h}$ & - \\
\hline Skowsky, W. R. (14) & $0.7 \mathrm{ng} / 1$ & $10.8 \mathrm{ng} / 1$ & $84 \%$ & $120 \mathrm{~h}$ & \\
\hline
\end{tabular}

* where absolute concentrations could not be derived, data are adopted as specified in the cited publication 
The radioimmunoassay consistently yielded a detection limit of $0.3 \mathrm{ng} / \mathrm{l}$ after only $2 \times 20 \mathrm{~h}$ of incubation. In other methods, much longer incubation times are needed to obtain a comparably low detection limit (tab. 1). The present assay can therefore be considered as both highly sensitive, and more rapid than other assays.

Arginine ${ }^{8}$-vasopressin immunoreactivity determined in plasma was characterized by reverse-phase high performance liquid chromatography. Immunoreactive arginine $^{8}$-vasopressin was coeluted with synthetic arginine $^{8}$-vasopressin as a single peak, confirming the specificity of the assay.

Isoosmotic arginine ${ }^{8}$-vasopressin suppression by central volume stimulation during water immersion (30, 31) was clearly demonstrated in accordance with the findings of other groups, supporting the concept of inhibition of arginine ${ }^{8}$-vasopressin secretion by acute atrial distension $(32,33)$.

Hypoosmolality as an osmotic stimulus of arginine - $^{8}$ vasopressin suppression (9) was confirmed by a significant decrease of plasma arginine ${ }^{8}$-vasopressin concentrations and plasma osmolality after oral water loading. Both quantities were closely correlated.

In conclusion, this radioimmunoassay for arginine ${ }^{8}$ vasopressin can be considered as highly sensitive, accurate and rapid, and it can be easily established in any suitably equipped laboratory.

\section{Acknowledgements}

The technical assistance of $M$. Bauch is gratefully acknowledged. This study was supported by a grant from the Deutsche Forschungsgemeinschaft (GE 576/2-2).

\section{References}

1. Goldsmith, S. R., Francis, G. S., Cowley, Jr., A. W., Levine, T. B. \& Cohn, J. N. (1983) Increased arginine vasopressin levels in patients with congestive heart failure. J. Am. Coll. Cardiol. 1, 1385-1390.

2. Riegger, G. A. J., Liebau, G. \& Kochsiek, K. (1982) Antidiuretic hormone in congestive heart failure. Am. J. Med $72,49-52$

3. Kortas, C., Bichet, D. G., Rouleau, J. L. \& Schrier, R. W. (1986) Vasopressin in congestive heart failure. J. Cardiovasc. Pharmacol. 8, 107-110.

4. Ganguly, A. \& Robertson, G. L. (1980) Elevated threshold for vasopressin release in primary hyperaldosteronism. Clin. Res. 28, 330.

5. Robertson, G. L. (1978) Cancer and inappropriate antidiuresis. Biological markers of neoplasia: Basic and applied aspects. Elsevier-North Holland Publishing Co., pp. 277293.

6. Bartter, F. C. \& Schwartz, W. B. (1967) The syndrome of inappropriate secretion of antidiuretic hormone. Am. J. Med. 42, 790-806.

7. Norsk, P. \& Epstein, M. (1988) Effects of water immersion on arginine vasopressin release in humans. J. Appl. Physiol. $64,1-10$

8. Claybaugh, J. R., Pendergast, D. R., Davis, J. E., Akiba, C., Pazik, M. \& Hong, S. K. (1986) Fluid conservation in athletes: responses to water intake, supine posture, and immersion. J. Appl. Physiol. 61, 7-15.

9. Robertson, G. L., Mahr, E. A., Athar, S. \& Sinha, T. (1973) Development and clinical application of a new method for the radioimmunoassay of arginine vasopressin in human plasma. J. Clin. Invest. 52, 2340-2352.

10. Fyhrquist, F., Wallenius, M. \& Hollemans, H. J. G. (1976) Radioimmunoassay of vasopressin in unextracted plasma. Scand. J. Clin. Lab. Invest. 36, $841-847$.

11. Husain, M. K., Fernando, N., Shapiro, M., Kagan, A. \& Glick, S. M. (1973) Radioimmunoassay of arginine vasopressin in human plasma. J. Clin. Endocrinol. 37, 616625.

12. Von Ameln, H., Laniado, M., Röcker, L. \& Kirsch, K. A. (1985) Effects of dehydration on the vasopressin response to immersion. J. Appl. Physiol. 58, 114-120.

13. Camps, J., Martinez-Vea, A., Perez-Ayuso, R. M., Arroyo, V., Gaya, J. M. \& Rivera-Fillat, F. (1983) Radioimmunoassay for arginine-vasopressin in cold ethanol extracts of plasma. Clin. Chem. 29, 882-884.

14. Skowsky, W. R., Rosenbloom, A. A. \& Fisher, D. A. (1974) Radioimmunoassay measurement of arginine vasopressin in serum: development and application. J. Clin. Endocrinol. Metab. 38, 278-287.

15. La Rochelle, T., North, G. \& Stern, P. (1980) A new extraction of arginine vasopressin from blood: the use of octadecasilyl-silica. Pflüg. Arch. 387, 79-81.

16. Samson, W. K. (1985) Atrial natriuretic factor inhibits dehydration and hemorrhage-induced vasopressin release. Neuroendocrinology 40, 277-279.

17. Gerbes, A. L., Wernze, H., Arendt, R. M., Riedel, A., Sauerbruch, T. \& Paumgartner, G. (1989) Atrial natriuretic factor (ANF) and renin-aldosterone in volume regulation of patients with cirrhosis. Hepatology 9, 417-422.

18. Gerbes, A. L., Arendt, R. M., Schnizer, W., Silz, S., Jüngst, D., Zähringer, J. \& Paumgartner, G. (1986) Regulation of atrial natriuretic factor release in man: effect of water immersion. Klin. Wochenschr. 64, 666-667.

19. Gerbes, A. L. \& Vollmar, A. M. (1988) Water immersion increases the concentration of the immunoreactive N-terminal fragment of pro-atrial natriuretic factor in human plasma. Biochem. Biophys. Res. Comm. 156, 228-232.

20. Permutt, M. A., Parker, C. W. \& Utiger, R. D. (1966) Immunochemical studies with lysine vasopressin. Endocrinology 78, 809-814.

21. Wu, W. H. \& Rockey, J. H. (1969) Antivasopressin antibody. Characterization of high-affinity antibody with limited association constant heterogeneity. Biochemistry 8 , 2719.

22. Miller, M. \& Moses, A. M. (1969) Radioimmunoassay of vasopressin with a comparison of immunological and biological activity in the rat posterior pituitary. Endocrinology $84,557-562$.

23. Edwards, C. R. W., Chard, T., Kitau, M. J. \& Forsling, M. L. (1970) The development of a radioimmunoassay and plasma extraction method for vasopressin. J. Endocrinol. $48,11-12$ 
24. Bichet, D. G., Kortas, C. \& Mettauer, B. (1986) Modulation of plasma platelet vasopressin by cardiac function in patients with heart failure. Kidney Int. 29, 1188-1196.

25. Bie, P. \& Warberg, J. (1983) Effect on intravascular pressures of vasopressin and angiotensin II in dogs. Am. J. Physiol. 245, R906-R914.

26. Bodola, F. \& Benedict, C. R. (1988) Rapid, simple radioimmunoassay of arginine-vasopressin and atrial natriuretic peptide in plasma. Clin. Chem. 34, 970-973.

27. Durr, J. A., Stamoutsos, B. \& Lindheimer, M. D. (1981) Osmoregulation during pregnancy in the rat. Evidence for resetting of the threshold for vasopressin secretion during gestation. J. Clin. Invest. 68, 373-346.

28. Keil, L. C. \& Severs, W. B. (1977) Reduction in plasma vasopressin levels of dehydrated rats following acute stress. Endocrinology 100, 30-38.

29. Ross, M. G., Ervin, M. G., Lam, R. W., Leake, R. D. \& Fisher, D. A. (1988) Fetal atrial natriuretic factor and arginine vasopressin responses to hyperosmolality and hypervolemia. Pediatr. Res. 24, 318-321.
30. Epstein, M., Preston, S. \& Weitzman, J. (1981) Isoosmotic central blood volume expansion suppresses plasma arginine vasopressin in normal man. J. Clin. Endocrinol. Metab. 52, $256-262$.

31. Norsk, P., Bonde-Petersen, F. \& Warberg, J. (1986) Arginine vasopressin, circulation, and kidney during graded water immersion in humans. J. Appl. Physiol. 61, 565574.

32. DeTorrente, A., Robertson, G. L., McDonald, K. M. \& Schrier, R. W. (1975) Mechanism of diuretic response to increased left atrial pressure in the anesthetized dog. Kidney Int. 8, 355-361.

33. Fater, D. C., Schultz, H. D., Sundet, W. D., Mapes, J. S. \& Goetz, K. L. (1982) Effects of left atrial stretch in cardiacdenervated and intact conscious dogs. Am. J. Physiol. 242, $\mathrm{H} 1056-\mathrm{H} 1065$

Dr. A. L. Gerbes

Med. Klinik II

Klinikum Großhadern

University of Munich

Marchioninistraße 15

W-8000 München

Bundesrepublik Deutschland 
, 